\title{
Idealism and the Aesthetics of Instrumental Music at the Turn of the Nineteenth Century
}

\author{
MARK EVAN BONDS
}

W ackenroder, Tieck, Novalis, Jean Paul, Friedrich Schlegel, E. T. A. Hoffmann: they are almost always summoned in a single breath as witnesses to the profound change in musical aesthetics that took place in Germany at the turn of the nineteenth century. Within the span of little more than a decade, these writers articulated the relatively sudden shift of instrumental music from the lowest to the highest of all musical forms, and indeed of all the arts in general. Long regarded as a liability, the vague content of instrumental music was now seen as an asset. In different ways and with different points of emphasis, these individuals all agreed that the more abstract nature of untexted music represented the true essence of the art, liberated from the strictures of mundane semantics.

The nature and origins of this new aesthetic remain problematic, however. Subsequent critics have typically portrayed this shift in outlook as a triumph of emotionalism over rationality. Wilhelm Heinrich Wackenroder, the first explicitly to voice this new perception of instrumental music, is routinely accused of Schwärmerei, that untranslatable transgression combining sentimentality with elements of ecstasy and dilettantism. Wackenroder himself anticipated that readers would dismiss his accounts of music as "idle Schwärmerei,"l a response that has in fact continued to the present day. In the entry on aesthetics in The New Grove Dictionary of Music and Musicians, for example, F. E. Sparshott blames Wackenroder's "rhapsodizing style" for having "permanently lowered the acceptable tone for serious writing on music. For the first time, cultivated men . . . conceived an unfocussed rapture to be a proper aesthetic response, thinking of musical

I am grateful to John Daverio, Jon Finson, James Haar, and J. Samuel Hammond for their comments on an earlier draft of this essay. I would also like to acknowledge the support of the National Endowment for the Humanities through a year-long fellowship at the National $\mathrm{Hu}-$ manities Center in the Research Triangle Park, North Carolina, during the academic year 1995-96.

1. Wilhelm Heinrich Wackenroder, Sämtliche Werke und Briefe: Historisch-kritische Ausgabe, ed. Silvio Vietta and Richard Littlejohns, 2 vols. (Heidelberg: Carl Winter Universitätsverlag, 1991), 1:206. 
techniques not as rational means of construction and expression but as occult mysteries." By this account, "Wackenroder's hysterically mystical view of music eventually invaded the writings of musicians themselves."2

Sparshott's formulation gives pointed expression to the varying degrees of embarrassment evident in most recent accounts of this new view of instrumental music. The emotional tone of writers like Wackenroder is generally deemed too personal to be derived from-or to provide the basis for-any systematic kind of aesthetic. Wackenroder and his collaborator Ludwig Tieck, moreover, expended at least as much energy praising the powers of vocal music and painting: their aesthetic was by no means limited strictly to instrumental music. Hoffmann, in turn, glorified not only Beethoven, but also Palestrina, Leo, and other masters of sacred music from the sixteenth through the early eighteenth centuries. ${ }^{3}$ And the characters in Wilhelm Heinse's novel Hildegard von Hohenthal (1795-96) rhapsodize for hundreds of pages on the emotional power of vocal music; their schwärmerisch tone continues a tradition going back at least three decades. Even while arguing for a "paradigm shift" to explain the new aesthetic of instrumental music, Carl Dahlhaus conceded that it "proceeded from the empfindsam music aesthetics of the 1780s and 1790s, and did so in a process of transformation that contemporaries must have found nearly imperceptible."4 In the end, the passionate tone of writers like Wackenroder, Tieck, and Hoffmann was simply not all that new.

More troubling still is the apparent discrepancy between the early Romantics' claims for the power of instrumental music and the actual repertory they described-or more to the point, did not describe. ${ }^{5}$ Wackenroder, Tieck, Novalis, and Jean Paul rarely named specific works or composers, and in those writings in which they did, their choices are all the more puzzling. Tieck, for example, discussed only a single work -an overture by Johann Friedrich Reichardt - in his important essay of 1799 on the symphony. This failure to address specific musical works or composers has led several generations of twentieth-century scholars to stake out the remarkable position that the visionary outpourings of the late 1790s anticipated a body of music yet to be composed, that the repeated references to "infinity" and "endless longing" in the works of Wackenroder, Tieck, and oth-

2. F. E. Sparshott, "Aesthetics of Music," in The New Grove Dictionary of Music and Musicians 1:127. Along similar lines, Carl Dahlhaus speaks of the "metaphysical excesses" of Tieck, Wackenroder, and Hoffmann (The Idea of Absolute Music, trans. Roger Lustig [Chicago: University of Chicago Press, 1989], 23-24; originally published as Die Idee der absoluten Musik [Kassel: Bärenreiter, 1978]).

3. E. T. A. Hoffmann, "Alte und neue Kirchenmusik" (1814), in his Schriften zur Musik, ed. Friedrich Schnapp (Munich: Winkler, 1963), 209-35.

4. Dahlhaus, Idea of Absolute Music, 2, 60.

5. Not wishing to offer yet another definition of Romanticism here, I shall use the terms early Romanticism and early Romantics as convenient designations for the last decade of the eighteenth century and the first decade of the nineteenth, and for the writers under consideration here who worked during that period. 
ers are more nearly congruous with the music of Beethoven's "late" style than with the works of Haydn, Mozart, or even early Beethoven. 6 Particularly adamant on this point, Dahlhaus argued that the Romantic aesthetic preceded Romantic music, and that Tieck's view of instrumental music "did not find an adequate object until E. T. A. Hoffmann borrowed Tieck's language in order to do justice to Beethoven." This new aesthetic, Dahlhaus maintained, "predicated the existence of instrumental music to which one could attach a poetically inspired metaphysics without embarrassing oneself with inappropriate dithyrambs."7

This barely concealed annoyance with Tieck ("inappropriate dithyrambs") rests on the mistaken assumption that changes in aesthetics were necessarily driven by changes in the contemporary musical repertory. In the case of early Romantic views of instrumental music, nothing could be further from the truth. The new aesthetics of instrumental music reflected fundamental transformations in contemporary philosophy and general aesthetics that were unrelated to the music of the time. These changes were not entirely without precedent, of course, for in one sense, the new-found prestige of instrumental music represented the culmination of a long and gradual process whose philosophical and aesthetic roots stretched back at least a century if not more. ${ }^{8}$ But the tempo of change accelerated dramatically in the last decade of the eighteenth century, and the most important catalyst for the emergence of this new aesthetic was the revival of idealism as a philosophical and aesthetic principle.

\section{The Idealist Aesthetic}

A venerable tradition of thought that traces its origins to the philosophies of Pythagoras, Plato, and Plotinus, idealism enjoyed a vigorous renewal in German philosophy and aesthetics toward the end of the eighteenth century through such figures as Johann Joachim Winckelmann, Karl Philipp

6. See Hugo Goldschmidt, Die Musiküsthetik des 18. Jabrhunderts (Zurich and Leipzig: Rascher, 1915), 210, 221, where Wackenroder is called "a prophet" whose theories "do not fit any music of the time" and the "apologist for Beethoven's late style" twenty years before the fact. Edward Lippman, in his History of Western Musical Aesthetics (Lincoln: University of Nebraska Press, 1992), also senses a disjuncture between aesthetics and repertory in the writings of the early Romantics, arguing that music corresponding to their ideas did not begin to emerge until the 1820s and 1830s (pp. 121, 239). Martin Geck (Von Beethoven bis Mabler: Die Musik des deutschen Idealismus [Stuttgart: J. B. Metzler, 1993], 96, 129) makes a similar claim. I shall return to Tieck's essay below.

7. Dahlhaus, Idea of Absolute Music, 90, 65; see also 103. See also idem, "Romantische Musikästhetik und Wiener Klassik," Archiv für Musikwissenschaft 29 (1972): 167-81.

8. See Jost Hermand, Konkretes Hören: Zum Inhalt der Instrumentalmusik (Berlin: Argument-Verlag, 1981); Bellamy Hosler, Changing Aesthetic Views of Instrumental Music in Eighteenth-Century Germany (Ann Arbor: UMI Research Press, 1981); and especially John Neubauer, The Emancipation of Music from Language: Departure from Mimesis in EighteenthCentury Aesthetics (New Haven: Yale University Press, 1986). 
Moritz, Immanuel Kant, Friedrich Schiller, Christian Gottfried Körner, Johann Gottfried Herder, Johann Gottlieb Fichte, and Friedrich Schelling. At first glance, the "rhapsodizing style" of Wackenroder and Tieck might seem to have little in common with the more sober discourse of Winckelmann, Moritz, and Kant, yet these earlier writings provided the essential framework for what are widely considered to be the first outpourings of Romantic musical aesthetics. ${ }^{9}$

In the broadest terms, idealism gives priority to spirit over matter. Without necessarily rejecting the phenomenal world, it posits a higher form of reality in a spiritual world beyond: objects in the phenomenal worldincluding works of art-are understood as reflections of noncorporeal ideals. From an aesthetic standpoint, idealism holds that art and the external world are consonant with one another not because art imitates that world, but because both reflect a common, higher ideal. Through idealism, the work of art became a central means by which to sense the realm of the spiritual, the infinite. ${ }^{10}$ By the early nineteenth century, the field of aesthetics was beginning to emerge as "the basic discipline and the organ of metaphysics." 11

Idealism thus stands in marked contrast to the eighteenth-century predilection for explaining the emotional power of music in essentially naturalistic or mechanical terms - that is to say, in terms of its effect on the listener. As a philosophy, naturalism rejects the notion that anything in the universe lies beyond the scope of empirical explanation; it holds that

9. Elements of idealist thought have been recognized in the writings of the early Romantics on many occasions, particularly in the scholarship of the late nineteenth and early twentieth centuries, but the application of idealist vocabulary and premises to the aesthetics of instrumental music has never been addressed in any systematic fashion. The entry for Schelling in Die Musik in Geschichte und Gegenwart, for example, makes no reference at all to the implications of idealism for contemporary perceptions of instrumental music. Hans Heinrich Eggebrecht, in turn (Musik im Abendland: Prozesse und Stationen vom Mittelalter bis zur Gegenwart [Munich: Piper, 1991], 592-621), rightly emphasizes the importance of the idea of music existing in its own separate world for early Romantic aesthetics, but does not relate this outlook to idealism. Many recent scholars, moreover, seem oddly reluctant to recognize the presence of idealist concepts in writings issued at the turn of the nineteenth century: Sparshott, for example ("Aesthetics of Music"), begins his account of idealism with Hegel, while Dahlhaus (Idea of Absolute Music, 10, 129) attributes an "aesthetic of essences" to Schopenhauer, Nietzsche, and the late Wagner, but not to earlier writers. Dahlhaus and others, as I shall argue below, also blur the crucial distinction between idealist aesthetics and the later doctrine of "absolute" music.

10. Introductions to the earlier history of idealism in aesthetics may be found in Erwin Panofsky, Idea: A Concept in Art Theory, trans. Joseph J. S. Peake (Columbia: University of South Carolina Press, 1968); Hans Zeller, Winckelmanns Beschreibung des Apollo im Belvedere (Zurich: Atlantis, 1955), 130-34; and Giorgio Tonelli, "Ideal in Philosophy: From the Renaissance to 1780," in The Dictionary of the History of Ideas, ed. Philip P. Wiener, 4 vols. (New York: Charles Scribner's Sons, 1973), 2:549-52.

11. Arnold Hauser, The Social History of Art, vol. 3, Rococo, Classicism and Romanticism, trans. Stanley Godman (London: Routledge and Kegan Paul, 1962), 108. 
the mind and spiritual values have their origins in (and can ultimately be reduced to) material things and processes. ${ }^{12}$ Naturalism provided the philosophical basis for mimesis, the aesthetic doctrine that prevailed before 1800 to explain the power of instrumental music. By imitating nature or the human passions, a work of art, critics argued, could induce a corresponding emotional reaction in the mind and spirit of the listener.

But music never fit very well into the mimetic system, which had evolved around the more overtly representational arts of poetry, painting, and sculpture. By the second half of the eighteenth century, most critics viewed direct musical imitations of the external world with skepticism and at times outright derision. Human passions provided a more appropriate object of imitation, for here, as Jean-Jacques Rousseau pointed out, the composer "does not directly represent" in his music such things as rain, fire, tempests, and the like, but instead "arouses in the spirit" of the listener "the same impulses that one experiences when beholding such things." 13 Still other writers opted for theories of "expression," but these systems ultimately depended on the principle of mimesis as well. ${ }^{14}$ Even those relatively few eighteenth-century writers who rejected musical mimesis altogether and espoused a kind of protoformalistic sensualism hastened to point out that music without a text was a merely agreeable (angenebme) art that stood beneath reason and thus outside the higher realm of the fine arts. Because it involved the free interplay of forms rather than of concepts, instrumental music was widely perceived, in Kant's oft-quoted formulation, to be "more pleasure than culture."15

Many eighteenth-century writers-including Johann Mattheson, Charles Batteux, Johann Joachim Quantz, Rousseau, Johann Nikolaus

12. H. B. Acton, "Idealism," in The Encyclopedia of Philosophy, ed. Paul Edwards, 8 vols. (New York: Macmillan, 1967), 4:110-18. See also Arthur C. Danto, "Naturalism," in The Encyclopedia of Philosophy 5:448-50.

13. Jean-Jacques Rousseau, "Imitation," in his Dictionnaire de musique (Paris, 1768; reprint, Hildesheim: Georg Olms, 1969): "Il ne représentera pas directement ces choses; mais il excitera dans l'âme les mêmes mouvemens qu'on éprouve en les voyant."

14. The classic formulation of the broader shift from mimesis to expression in all the arts remains M. H. Abrams, The Mirror and the Lamp: Romantic Theory and the Critical Tradition (New York: Oxford University Press, 1953). On music in particular, see Hans Heinrich Eggebrecht, "Das musikalische Ausdrucksprinzip im 'Sturm und Drang," Deutsche Vierteljabrsschrift für Literaturwissenschaft und Geistesgeschichte 29 (1955): 323-49; and Hosler, Changing Aesthetic Views. On the close relationship between mimesis and "expressive" theories, see Neubauer, Emancipation of Music, 149-67.

15. See, for example, the excerpt from Boyé, L'expression musicale, mise au rang des chimères (Amsterdam, 1779), translated by Edward Lippman in his Musical Aesthetics: A Historical Reader, 2 vols. (New York: Pendragon, 1986-88), 1:294: "The principal object of music is to please us physically, without the mind purting itself to the trouble of searching for useless comparisons to it. One should regard it 'entirely as a pleasure of the senses and not of the intelligence." Immanuel Kant, Kritik der Urteilskraft (1790), ed. Raymund Schmidt (Leipzig: Reclam 1956), 237 (section 53): "mehr Genuß als Kultur." 
Forkel, Johann Georg Sulzer, and Heinrich Christoph Koch - sought to elevate the aesthetic status of instrumental music by calling it "the language of the heart" or "the language of the emotions." 16 Yet this approach could not adequately overcome the problem of vagueness, for to speak of music as a language of any kind was to place it within a conceptual model that inevitably worked against music without a text: a lack of precision could scarcely qualify as a desirable linguistic quality. Within the framework of naturalism, moreover, the language model failed to explain the actual process of cause-and-effect by which music could move the passions of its listeners.

Idealism, by contrast, made no effort to explain the reaction of the individual perceiving any given work of art, positing instead that the aesthetic effect of an artwork resides in its ability to reflect a higher ideal. An individual's response to a given work of art, in other words, was seen as a reaction not so much to the work itself as to the ideal manifested in that work. Idealism did not deny the emotional power of music. To the contrary: the aesthetics of idealism fostered some of the most soaring descriptions of instrumental music ever written. The object of description, however, had shifted from music's effect to music's essence, or more specifically, to the ideal realm reflected in that music. ${ }^{17}$ Within the idealist aesthetic, then, instrumental music remained an imprecise art, but with the essential difference that this imprecision was no longer perceived in relation to nature, language, or human emotions, but rather in relation to a higher, ideal world-to that "wondrous realm of the infinite" ("das wundervolle Reich des Unendlichen"), to use Hoffmann's celebrated phrase. From this perspective, vagueness was no vice. Commentators no longer felt compelled to engage in the futile (and inevitably trivializing) effort to specify the objective "content" of instrumental music. Instead, they changed the venue of contemplation from the material to the spiritual, from the empirical to the ideal. Freed from the obligation to explain the causal mechanism of their responses to music, idealist critics could revel in those responses all the more freely. One can, after all, be more readily forgiven for resorting to metaphorical excess in trying to describe the infinite, as opposed to one's personal reaction to a specific work of art. The early Romantics were most assuredly not the first to respond deeply and passionately to instrumental music; they were, however, members of the first

16. See Hosler, Changing Aesthetic Views; Neubauer, Emancipation of Music; and Mark Evan Bonds, Wordless Rhetoric: Musical Form and the Metaphor of the Oration (Cambridge: Harvard University Press, 1991), 61-68.

17. Neubauer's interpretation of early Romantic music aesthetics as a revival of Pythagoreanism is correct insofar as Pythagoreanism is itself one particular manifestation of idealism. The examples in his "Epilogue on Romanticism" (Emancipation of Music, 193-210) become more persuasive when viewed within this broader context. 
generation to have at its disposal a philosophical framework in which to express such powerful emotions without embarrassment.

Not surprisingly, the early Romantics described the very act of listening in fundamentally new terms. All aesthetic contemplation, according to the idealist outlook, demanded imagination-Einbildungskraft - to mediate between the senses and the spirit, between the phenomenal and the noumenal worlds. Indeed, the term itself, as used by Lessing, Kant, and Fichte, among others, combined an inward-directed activity ("Ein-bildung") with a sense of constructive power ("-kraft"). ${ }^{18}$ Christian Gottfried Körner, writing in 1795, emphasized that we value an artistic work "not by what appears in it, but according to what must be thought," that is, according to the reflective process demanded by the particular work. ${ }^{19}$ For Körner and other idealists, the enjoyment of art was not a process of "idle reception," but rather of "activity." Late eighteenth-century aesthetics thus moved from the premise of passive effect (Wirkung) to what Wackenroder and Herder would characterize as reverent contemplation (Andacht). The new scenario rendered the listener less important in some respects but more important in others: less important in that the musical work's essence-as opposed to its effect-had become the focus of attention, and more important in that the listener was obliged to take an active role in the mental construction of that work within his or her own sphere of perception.

The novelty of this approach - which we tend to take for granted today - can be readily illustrated by contrasting two accounts of listening, one from 1739, the other from 1792. Both resonate with passion, but their aesthetic premises differ fundamentally. "When I hear a solemn symphony in church," Mattheson confessed in 1739, "a sense of reverential awe falls over me. If an instrumental chorus joins in, this brings about an elevated sense of wonder within me. If the organ begins to storm and thunder, a divine fear arises in me. And if everything concludes with a joyful Halleluia, my heart leaps within my body."20 For Mattheson, listening was an intense

18. Kant's Kritik der Urteilskraft (1790) was particularly important in this regard. Recent accounts of the growing role of imagination in the eighteenth century include Lillian Furst, Romanticism in Perspective, 2d ed. (London: Macmillan, 1979), 119-209; James Engell, The Creative Imagination: Enlightenment to Romanticism (Cambridge: Harvard University Press, 1981); and Mark Johnson, The Body in the Mind: The Bodily Basis of Meaning, Imagination, and Reason (Chicago: University of Chicago Press, 1987), 139-72.

19. Christian Gottfried Körner, "Ueber Charakterdarstellung in der Musik," in Wolfgang Seifert, Christian Gottfried Körner: Ein Musikästhetiker der deutschen Klassik (Regensburg: Gustav Bosse, 1960), 151: "Wir schätzen die Erscheinung nach demjenigen, was in ihr nicht erscheint, sondern gedacht werden muss." Emphasis in the original.

20. Johann Mattheson, Der vollkommene Capellmeister (Hamburg, 1739; reprint, Kassel: Bärenreiter, 1954), 208-9: "Vernehme ich in der Kirche eine feierliche Symphonie, so überfällt mich ein andächtiger Schauder; arbeitet ein starcker Instrumenten-Chor in die Wette, so bringt mir solches eine hohe Verwunderung zu Wege; fängt das Orgelwerck an zu brausen 
but ultimately passive process, in contrast to the "true way of listening" that Wackenroder described in 1792 in a letter to Tieck:

It consists of the most attentive observations of the notes and their progression; in the complete surrender of the soul to this torrential stream of emotions; in the distancing and withdrawal from every disruptive thought and from all extraneous sensuous impressions. For me, this voracious quaffing of the notes is associated with a certain strain that cannot be tolerated for all that long. And for this reason, I believe I may assert that one is capable of perceiving music in a participatory manner for one hour at the most. ${ }^{21}$

In keeping with the mimetic aesthetic of his time, Mattheson had described the listening experience in terms of cause and effect; Wackenroder, as an idealist, saw it as an integration of emotional receptivity and an active, even strenuous, imagination, a "voracious quaffing of the notes." This is not to suggest that Mattheson and his contemporaries used no imagination while listening to instrumental music, or that their aesthetic response to this music was somehow less intense than that of Wackenroder and other early Romantics. But the new premise of a participatory imagination in the act of aesthetic perception had changed the acceptable modes and purpose of describing that perception.

To sum up thus far: the idealist aesthetic assumes that anyone contemplating a work of art can and must mentally reconstruct that work before it can exercise a significant emotional effect. As an aesthetic based on the philosophical premise of a free and absolute self, idealism accommodates multiple and widely differing interpretations of a given work of music. Under the doctrine of mimesis, conflicting interpretations of the emotional content of an instrumental work had long been perceived as an inevitable consequence of the presumed deficiencies of instrumental music itself. The implicitly derisive question attributed to the philosophe Bernard de

und zu donnern, so entstehet eine göttliche Furcht in mir; schliesst sich denn alles mit einem freudigen Hallelujah, so hüpfft mir das Hertz im Leibe.” Mattheson goes on to note that the effect of the vocal music would still be powerful even if for some reason he did not know the meaning of the words being sung.

21. Wackenroder to Tieck, 5 May 1792, in his Sämtliche Werke 2:29:

Wenn ich in ein Konzert gehe, find' ich, daß ich immer auf zweyerley Art die Musik genieße. Nur die eine Art des Genußes ist die wahre: sie besteht in der aufmerksamsten Beobachtung der Töne u[nd] ihrer Fortschreitung; in der völligen Hingebung der Seele, in diesen fortreißenden Strohm von Empfindungen; in der Entfernung und Abgezogenheit von jedem störenden Gedanken und von allen fremdartigen sinnlichen Eindrücken. Dieses geizige Einschlürfen der Töne ist mir einer gewissen Anstrengung verbunden, die man nicht allzulange aushält. Eben daher glaub' ich behaupten zu können, daß man höchstens eine Stunde lang Musik mit Theilnehmung zu empfinden vermöge.

The other method Wackenroder describes is to allow the music to provoke images in his mind, without paying such close attention to the actual course of the notes themselves-in other words, to use the music as a stimulus to the fantasy, rather than to use the fantasy as a stimulus to the "quaffing" of the music. Ironically, this less satisfactory mode of listening is the one that has been most often ascribed to writers like Wackenroder. 
Fontenelle - "Sonata, what do you want of me?"-resonated for as long as it did not merely because the mimetic nature of instrumental work was deemed unsatisfactory, but also because the very premise that the listener might have to "work" while listening was itself so audacious. ${ }^{22}$ Within the idealist aesthetic, listeners were expected to "work" with their imagination, and the fact that instrumental music could generate widely differing accounts of its content was accepted as a consequence of this music's capacity to reflect a higher ideal. That this ideal might be only partially comprehensible was scarcely a fault of the medium itself. For in the end, it was only through the work of art that the infinite could be sensed at all, however imperfectly.

\section{The Emergence of the Idealist Aesthetic in the Late Eighteenth Century}

The resurgence of aesthetic idealism in the eighteenth century owes much to the work of the archaeologist and art historian Johann Joachim Winckelmann (1717-1768), whose concept of ideal beauty drew heavily on Plato. ${ }^{23}$ For Winckelmann, the work of art did not imitate any single model in nature, but derived its features instead from a variety of different exemplars. The resulting "ideal figures, like an ethereal spirit purified by fire," were no mere composites, however: the high purpose of ancient Greek artists had been "to bring forth creations bestowed with a divine and suprasensory sufficiency" that were "freed from every human weakness." ${ }^{24}$ In

22. See Rousseau, "Sonate," in his Dictionnaire de musique, 452: "I shall never forget the outburst of the celebrated Fontenelle, who, finding himself overwhelmed by these endless symphonies, cried out quite loudly in a fit of impatience: 'Sonata, what do you want of me?' " ("Je n'oublierai jamais la saillie du célebre Fontenelle, qui se trouvant excédé des ces éternelles Symphonies, s'écria tout haut dans un transport d'impatience: sonate, que me veux-tu?").

23. "Idealism" is an extremely broad phenomenon, and the outline of its application to musical aesthetics presented here should not convey the impression that this mode of thought developed in a clear or linear fashion. Kant, Fichte, and Schelling - to name only three of the more prominent philosophers associated with this movement-each developed his own distinctive brand of idealism, and in the necessarily condensed account that follows, I have made no attempt to distinguish among idealism's various manifestations, such as subjective, objective, transcendental, and absolute, preferring instead to focus on the underlying similarities of these views as applied to instrumental music. Chronological priority is also difficult to establish in such a broad area. In one sense, Wackenroder and Tieck actually applied the aesthetics of idealism to instrumental music a few years before they were systematically formulated in Schelling's System des transcendentalen Idealismus (1800) and in his lectures at Jena (1802-3), later published as Die Philosophie der Kunst. But Schelling's formulations are anticipated to a certain extent by Kant, Schiller, and Körner in writings that date from the first half of the 1790s and thus precede those of Wackenroder and Tieck.

24. Johann Joachim Winckelmann, "Vorläufige Abhandlung zu den Denkmalen der Kunst des Altertums" (1767) in his Sämtliche Werke, ed. Joseph Eiselein, 12 vols. (Donauöschingen: Verlàg deutscher Classiker, 1825-35), 7:110. 
this sense, Winckelmann saw ideal beauty as deriving at least in part from the mind alone, independent of direct reference to experience. And although he at one point explicitly denied that ideal beauty holds any metaphysical significance, he argued elsewhere that the ideally beautiful has its archetype in God. ${ }^{25}$ Herder accurately summed up the reception of Winckelmann's epoch-making Geschichte der Kunst des Altertums (1764) in describing the work not so much as an actual history of art than as a "historical metaphysics of beauty."26

Plato's theories of beauty are equally evident in the Allgemeine Theorie der schönen Künste (1771-74) of the Swiss aesthetician Johann Georg Sulzer (1720-1779). Here, Sulzer followed the Greek philosopher's distinction among various categories of artistic imitation and idealization. The first and lowest category of artists consists of those who copy nature precisely and without discrimination. Artists who imitate nature more selectively belong to the second, higher category. The third and highest category consists of those for whom nature is not sufficient and who pursue the images of ideal forms. "One can generally say about an artwork that has not been copied from an object in nature that it has been made according to an Ideal, if it has received its essence and form from the genius of the artist." ${ }^{27}$ But it apparently never occurred to Sulzer or anyone else of his generation to align instrumental music (or any kind of music) with the concept of the ideal; to do so would have been to elevate what was considered a merely pleasant form of diversion to the highest ranks of the fine arts - which is precisely what many of the Romantics would later do.

Karl Philipp Moritz (1757-1793) helped lay the foundation for this development in his later writings. From 1789 until his death, he lectured in Berlin on antiquity, mythology, and the history of art, and his audiences included Wackenroder, Tieck, Alexander von Humboldt, and the composer Johann Friedrich Reichardt. Moritz openly rejected mimesis as a basis of art, insisting instead that the true artwork must be self-contained and internally coherent, and that it must exist for its own sake. He placed special emphasis on the act of aesthetic contemplation. In his "Essay on the Unification of All the Fine Arts and Sciences Under the Concept of the Perfected Thing in Itself," he proclaimed that "in contemplating the beautiful,

25. See Frederic Will, "Winckelmann and the Ideal of Beauty," chap. 6 of his Intelligible Beauty in Aesthetic Thought, from Winckelmann to Victor Cousin (Tübingen: Max Niemeyer, 1953).

26. Johann Gottfried Herder, "Erstes Kritisches Wäldchen" (1769), in his Schriften zur Asthetik und Literatur, 1767-1781, ed. Gunter E. Grimm (Frankfurt am Main: Deutscher Klassiker Verlag, 1993), 66.

27. Johann Georg Sulzer, Allgemeine Theorie der schönen Künste, 2 vols. (Leipzig: M. G. Weidemanns Erben und Reich, 1771-74), "Ideal": "Man kann überhaupt von jedem Gegenstand der Kunst, der nicht nach einem in der Natur vorhandenen abgezeichnet worden, sondern sein Wesen und seine Gestalt von dem Genie des Künstlers bekommen hat, sagen, er sey nach einem Ideal gemacht." 
... I contemplate the object not as something within me, but rather as something perfect in itself, something that constitutes a whole in itself and gives me pleasure for the sake of itself, in that I do not so much impart to the beautiful object a relationship to myself but rather impart to myself a relationship to it." 28 For Moritz, the contemplation of the beautiful carried the added benefit of drawing attention away from the ills of mortal existence, if only momentarily. "This forgetting of the self is the highest degree of the pure and unselfish pleasure that beauty grants us. At that moment we give up our individual, limited existence in favor of a higher kind of existence." 29

The belief that arts in general, and music in particular, can provide refuge from the failed world of social and political life is a touchstone of Romantic aesthetics. Franz von Schober's poem "An die Musik," set to music by Schubert in 1817, is one of the better-known poetic expressions of this phenomenon ("Du holde Kunst, in wieviel grauen Stunden, / . . . hast mich in eine bess're Welt entrückt!"). In a diary entry from the previous year, Schubert himself had observed that Mozart's music "shows us in the darknesses of this life a light-filled, bright, beautiful distance, toward which we can aspire with confidence." 30 When listening to music, Wackenroder's fictional Joseph Berglinger forgets "all earthly trivialities that are truly dust on the radiance of the soul"; this trivial dust is "cleansed" by music. ${ }^{31}$ Tieck declares the modern symphony to be capable of "redeeming us from the conflict of wayward thoughts" and leading us "to a quiet, happy, peaceful land," while Hoffmann perceives a "wondrous spirit-realm of the infinite"

28. Karl Philipp Moritz, "Versuch einer Vereinigung aller schönen Künste und Wissenschaften unter dem Begriff des in sich selbst Vollendeten" (1785), in his Schriften zur Ästhetik und Poetik, ed. Hans Joachim Schrimpf (Tübingen: Max Niemeyer, 1962), 3: "ich betrachte ihn [the beautiful object], als etwas, nicht in mir, sondern in sich selbst Vollendetes, das also in sich ein Ganzes ausmacht, und mir um sein selbst willen Vergnügen gewährt; indem ich dem schönen Gegenstande nicht sowohl eine Beziehung auf mich, als mir vielmehr eine Beziehung auf ihn gebe." Emphasis in the original.

29. Moritz, "Versuch," 5: "dies Verlieren, dies Vergessen unsrer selbst, ist der höchste Grad des reinen und uneigennützigen Vergnügens, welches uns das Schöne gewährt. Wir opfern in dem Augenblick unser individuelles eingeschränktes Dasein einer Art von höherem Dasein auf." Moritz's novel Andreas Hartknopf (1786) contains similar imagery, even while adhering to the conventional metaphor of music as the "language of emotions."

30. Quoted in Otto Erich Deutsch, Schubert: Die Dokumente seines Lebens (Kassel: Bärenreiter, 1964), 42-43: "Die Zaubertöne von Mozarts Musik ... zeigen uns in den Finsternissen dieses Lebens eine lichte, helle, schöne Ferne, worauf wir mit Zuversicht hoffen.” On the early nineteenth-century idea of music as a utopian realm, see Max Becker, Narkotikum und Utopie: Musik-Konzepte in Empfindsamkeit und Romantik (Kassel: Bärenreiter, 1996).

31. Wackenroder, Herzensergiessungen, "Das merkwürdige musikalische Leben des Tonkünstlers Joseph Berglinger," in his Sämtliche Werke 1:132: "Die Gegenwart versank vor ihm; sein Inneres war von allen irdischen Kleinigkeiten, welche der wahre Staub auf dem Glanze der Seele sind, gereinigt." 
through the prism of Beethoven's Fifth Symphony. ${ }^{32}$ Even Beethoven himself is alleged to have urged a ten-year-old admirer, "not only cultivate your art, but penetrate to its innermost; it deserves this, for only art and science elevate mankind to the divine." ${ }^{33}$ And Bettina von Arnim, in her fictional report of conversations with the composer, first published in 1835 , had Beethoven declare, "When my music makes itself understood to someone, that person becomes free of all the misery that the rest of mankind carries as its burden." 34 While not necessarily representative of Beethoven's own thought, Arnim's account is certainly representative of its time.

It was not until 1790 , however, that the aesthetics of idealism received its first systematic treatment in the Kritik der Urteilskraft of Immanuel Kant (1724-1804). Like Moritz, Kant emphasized the creativity of reception and the "play of mental powers" in aesthetic judgment, and in his "Critique of Judgment," he established a philosophical basis for connecting reason with the senses. It is not too much of an exaggeration to say that after Kant, beauty would no longer be defined as a quality within a given object, but rather as a function of subjective, aesthetic pleasure.

For Kant, spirit-Geist-is the "ability to present aesthetic ideas." He defined an "aesthetic idea," in turn, as "that representation of the imagination which induces much thought, yet without the possibility of any definite thought, i.e., concept, being adequate to it." This representation of the imagination, consequently, "can never be completely realized or rendered intelligible through language. One can easily see that it is the counterpart (pendant) of a rational idea, which is, conversely, a concept to which no intuition (or representation of the imagination) can be ade-

32. Tieck, Phantasien, "Symphonien," in Wackenroder, Sämtliche Werke 1:241: "aus dem Streit der irrenden Gedanken in ein stilles, heiteres, ruhiges Land erlöst zu werden"; Hoffman, review of Beethoven's Fifth Symphony (1810) in his Schriften zur Musik, 37: "das wundervolle Geisterreich des Unendlichen." Idealism played an important role in contemporary German theories of the state, and in this respect, Hoffmann's review of Beethoven's Fifth can be seen to reflect certain political ideas of his time: see Stephen Rumph, "A Kingdom Not of This World: The Political Context of E. T. A. Hoffmann's Beethoven Criticism," 19thCentury Music 19 (1995): 50-67. But in the end, Hoffmann's response is motivated less by political circumstances than by broader philosophical, aesthetic, and ethical ideals.

33. Beethoven to "Emilie M. in H[amburg]," 17 July 1812, in his Briefivechsel: Gesamtausgabe, ed. Sieghard Brandenburg, 6 vols. (Munich: G. Henle, 1996), 2:274: "übe nicht allein die Kunst, sondern dringe auch in ihr Inneres; sie verdient es, denn nur die Kunst und die Wissenschaft erhöhen den Menschen bis zur Gottheit." No autograph of the letter survives. Note the similarity to Goethe's Zabme Xenien IX, first published in 1827: "Wer Wissenschaft und Kunst besitzt, / Hat auch Religion; / Wer jene beiden nicht besitzt, / Der habe Religion.”

34. Bettina von Arnim, Goethes Briefiwechsel mit einem Kind, ed. Gustav Konrad (Frechen: Bartmann, 1960), 246 ("letter" of 28 May 1810): "wem sie [Beethoven's own music] sich verständlich macht, der muß frei werden von all dem Elend, womit sich die andern schleppen." 
quate."35 But Kant explicitly rejected the notion that purely instrumental music might incorporate aesthetic ideas; it could be judged only on the basis of its form. He therefore relegated instrumental music-along with wallpaper - to the category of "free beauty." 36 Vocal music, by contrast, belonged to the higher category of "dependent beauty" on the grounds that its text allowed the listener to find correlatives in the concepts of the objects being represented.

In this dichotomy of "free" and "dependent" beauty, Kant suggested an alternative approach to the evaluation of instrumental music, for as an instance of "free beauty," such music could be evaluated exclusively from the perspective of form. This line of thought presented an important opening to formalists in the mid-nineteenth century, most notably Eduard Hanslick. But for Kant, "free beauty" was a decidedly inferior category of art, because the contemplation of mere form, without concepts, would eventually "make the spirit dull, the object repulsive, and the mind . . . discontented with itself and ill-humored." $37 \mathrm{He}$ dismissed any ideas one might experience while listening to instrumental music as mere mechanical byproducts of associative thought. Unlike poetry, music speaks "only through sentiments and without concepts, and thus . . . leaves nothing to be contemplated." It was on this basis that he deemed untexted music to be "more pleasure than culture," even while affirming its potential emotional power. ${ }^{38}$

From the standpoint of aesthetic cognition, then, Kant's ideas were extremely advanced for his time; but in applying these principles to instrumental music, he retreated to the traditional model of that art as at best a semiarticulate "language of the emotions." As Edward Lippman has noted, however, Kant's inadequate treatment of instrumental music had the positive value of spurring later writers to reconcile this art with an aesthetic of the beautiful, as opposed to an aesthetic of the merely agreeable. ${ }^{39}$

One of the most influential of these post-Kantian writers was Friedrich von Schiller (1759-1805), who developed the tenets of aesthetic idealism

35. Kant, Kritik der Urteilskraft, 216 (section 49): "unter einer ästhetischen Idee . . verstehe ich diejenige Vorstellung der Einbildungskraft, die viel zu denken veranlaßt, ohne daß ihr doch irgendein bestimmter Gedanke d. i. Begriff adäquat sein kann, die folglich keine Sprache völlig erreicht und verständlich machen kann. Man sieht leicht, daß sie das Gegenstück (Pendant) von einer Vernunftidee sei, welche umgekehrt ein Begriff ist, dem keine Anschauung (Vorstellung der Einbildungskraft) adäquat sein kann.”

36. Ibid., 95-96 (section 16).

37. Ibid., 234 (section 52).

38. Ibid., 237 (section 53). Philip Alperson ("The Arts of Music," Journal of Aesthetics and Art Criticism 50 [1992]: 217-30, at 221-23) points out certain ambiguities in the treatment of instrumental music in the Kritik der Urteilskraft, suggesting that Kant may well have held "higher" forms (as opposed to mere Tafelmusik; see 204-5, section 44) in greater esteem, even while conceding that Kant never states this position explicitly.

39. Lippman, History of Western Musical Aesthetics, 133. 
in a series of widely read essays dating from the mid 1790s, beginning with an extended review of a collection of poetry by Friedrich von Matthisson. In a remarkable passage that anticipates Hanslick by some sixty years, Schiller argued that "although the content of emotions cannot be represented" in any work of art, "the form certainly can be." Schiller went on to point out that there is in fact a "widely beloved and powerful art that has no other object than the form of these emotions. This art is Music."40

In short, we demand that in addition to its expressed content, every poetic composition at the same time be an imitation and expression of the form of this content and affect us as if it were music....

Now the entire effect of music, however (as a fine art, and not merely as an agreeable one), consists of accompanying and producing in sensuous form the inner movements of the emotions through analogous external motions. ... If the composer and the landscape painter penetrate into the secret of those laws that govern the inner movements of the human heart, and if they study the analogy that exists between these movements of the emotions and certain external manifestations, then they will develop from merely ordinary painters into true portraitists of the soul. They will leave the realm of the arbitrary and enter the realm of the necessary. And they may justly take their places not beside the sculptor, who takes as his object the external human form, but rather beside the poet, who takes as his object the inner human form. ${ }^{41}$

While still essentially mimetic in its assumptions, Schiller's pronouncement moved the focus of debate away from content and toward form. Like Hanslick, Schiller denied that music itself embodies emotional content; rather, it works through a process of analogical structure, mediated by the

40. Friedrich Schiller, "Über Matthissons Gedichte" (1794), in his Werke und Briefe, ed. Otto Dann et al., 12 vols. (Frankfurt am Main: Deutscher Klassiker Verlag, 1992), 8:1023: "Zwar sind Empfindungen, ibrem Inhalte nach, keiner Darstellung fähig; aber ibrer Form nach sind sie es allerdings, und es existiert wirklich eine allgemein beliebte und wirksame Kunst, die kein anderes Objekt hat, als eben diese Form der Empfindungen. Diese Kunst ist die Musik." Emphasis in the original.

\section{Ibid., 1024-25:}

kurz wir verlangen, daß jede poetische Komposition neben dem, was ihr Inhalt ausdrückt, zugleich durch ihre Form Nachahmung und Ausdruck von Empfindungen sei, und als Musik auf uns wirke....

Nun besteht aber der ganze Effekt der Musik (als schöner und nicht bloß angenehmer Kunst) darin, die inneren Bewegungen des Gemüts durch analogische äußere zu begleiten und zu versinnlichen. . . . Dringt nun der Tonsetzer und der Landschaftmaler in das Geheimnis jener Gesetze ein, welche über die innern Bewegungen des menschlichen Herzens walten, und studiert er die Analogie, welche zwischen diesen Gemütsbewegungen und gewissen äußern Erscheinungen statt findet, so wird er aus einem Bildner gemeiner Natur zum wahrhaften Seelenmaler. Er tritt aus dem Reich der Willkür in das Reich der Notwendigkeit ein, und darf sich, wo nicht dem plastischen Künstler, der den äußern Menschen, doch dem Dichter, der den innern zu seinem Objekte macht, getrost an die Seite stellen.

Emphasis in the original. Schiller's review was widely discussed in its time and quoted extensively: see Dann's editorial comments in Schiller, Werke und Briefe 8:1543-46. 
listener's imagination. The poet retains the ability to direct the imagination of his audience in a more defined direction, but even this capacity is limited, for while the poet can "indicate those ideas and allude to those emotions, he cannot develop them himself." Above all, he must not preempt the imagination of his readers. An overly precise indication of ideas or emotions would constitute a "burdensome limitation," because the attractiveness of an aesthetic idea lies in our freedom to perceive its content in a "boundless profundity." "The actual and explicit content that the poet gives is always finite; the potential content, which he leaves for us to project into the work, is an infinite entity." 42

The "art of the infinite" and "infinite longing" play an even greater role in Schiller's celebrated essay "On Naive and Sentimental Poetry" of 179596. The dichotomy between the naive (the natural and sensuous) and the sentimental (the reflective and abstract) corresponds roughly to the phenomenal and noumenal. The task of the modern poet is to bridge the gulf between the two. But because this cannot be realized on earth, the poet's striving for such a synthesis must necessarily remain "infinite." The genius of sentiment, according to Schiller, "abandons [phenomenal] reality in order to ascend to ideas and to rule over his material with his own freedom of activity." ${ }^{\prime 3}$ In so doing, however, the artist runs the risk of devolving into a realm of meaningless abstraction. On precisely these grounds, Schiller elsewhere rejected those works of music by "recent"- unnamedcomposers that appealed merely to the senses. ${ }^{44}$

Although Schiller was disinclined to comment at any length on the integration of the sensuous and the abstract in instrumental music, he helped establish a framework for the reevaluation of this art in the work of his close friend Christian Gottfried Körner (1756-1831), who happened to be an accomplished musician. Körner's essay "On the Representation of Character in Music" was first published in Schiller's journal, Die Horen, in 1795; and following Schiller's lead, Körner rejected Kant's notion that instrumental music constituted a merely agreeable art rather than a fine art. The

42. Schiller, "Über Matthissons Gedichte," 1026:

Andeuten mag er jene Ideen, anspielen jene Empfindungen; doch ausführen soll er sie nicht selbst, nicht der Einbildungskraft seines Lesers vorgreifen. Jede nähere Bestimmung wird hier als eine lästige Schranke empfunden, denn eben darin liegt das Anziehende solcher ästhetischen Ideen, daß wir in den Inhalt derselben wie in eine grundlose Tiefe blicken. Der wirkliche und ausdrückliche Gehalt, den der Dichter hineinlegt, bleibt stets eine endliche; der mögliche Gehalt, den er uns hinein zu legen überläßt, ist eine unendliche Größe.

43. Schiller, "Über naive und sentimentalische Dichtung" (1795-96), in his Werke und Briefe 8:786: "Das sentimentale Genie hingegen verlässt die Wirklichkeit, um zu Ideen aufzusteigen und mit freier Selbsttätigkeit seinen Stoff zu beherrschen." On the category of the infinite in early Romantic aesthetics in general, see Ursula Leitl-Zametzer, "Der Unendlichkeitsbegriff in der Kunstauffassung der Frühromantik bei Friedrich Schlegel und W. H. Wackenroder" (Ph.D. diss., Munich, 1955), a work whose scope extends well beyond the two writers named in its title.

44. Schiller, "Über das Pathetische," in his Werke und Briefe 8:427. 
purpose of an agreeable art, he argued, is to please its audience by moving the emotions, through the process of pathos. Works of fine art, by contrast, exist as self-contained entities; their purpose is the representation of character, or ethos. Early in his essay, Körner neatly summarized the historical stages of eighteenth-century thought regarding the questions of imitation and representation in music:

For a long time, the notion of what was worthy of representation in music was governed by remarkable prejudices. Here, too, there was fundamental misunderstanding about the principle that the imitation of nature should determine the art. For some, the mimicking of everything audible was considered the essential business of the composer, from the rolling of thunder to the crowing of the rooster. A better kind of taste gradually begins to spread. The expression of human sentiment replaces noise lacking a soul. But is this the point at which the composer is to remain, or is there a higher goal for him? ${ }^{45}$

The answer, he believed, is that the artist must go beyond the expression of transitory sentiment and complement that which is missing in individual, phenomenal exemplars: "He must idealize his material." Only through art, Körner maintained, can the infinite be made perceptible, however dimly, for outside of art it can only be imagined. Thus the artist "must raise us up to himself and represent the infinite in perceptible form." 46 For Körner, the characteristic is the symbolic manifestation of the ideal. Character is the concept through which the realms of morality and aesthetics are joined, and by associating music with moral character, Körner was able to elevate the status of instrumental music to that of a fine art. ${ }^{47} \mathrm{He}$ rejected the notion that music unsupported by dance, drama, or poetry could not, because of its vagueness, depict character. Rather, he strongly implied an essential equality between instrumental and vocal music, and while he did not pursue this point in detail, his brief essay represents an important advance in the emerging prestige of instrumental music.

45. Körner, "Ueber Charakterdarstellung," 147:

Über das Darstellungswürdige in der Musik herrschten lange Zeit seltsame Vorurtheile. Auch hier wurde der Grundsatz mißverstanden, daß Nachahmung der Natur die Bestimmung der Kunst sey; und Nachäffung alles Hörbaren vom Rollen des Donners bis zum Krähen des Hahns galt manchem für das eigenthümliche Geschäft des Tonkünstlers. Ein beßerer Geschmack fängt an, allgemeiner sich auszubreiten. Ausdruck menschlicher Empfindung tritt an die Stelle eines seelenlosen Geräusches. Aber ist dieß der Punkt, wo der Tonkünstler stehen bleiben darf, oder giebt es für ihn noch ein höheres Ziel?

46. Ibid., 148: "Was wir in der Wirklichkeit bei einer einzelnen Erscheinung vermißen, soll uns der Künstler ergänzen; er soll seinen Stoff idealisieren. In den Schöpfungen seiner Phantasie soll die Würde der menschlichen Natur erscheinen. Aus einer niedern Sphäre der Abhängigkeit und Beschränktheit soll er uns zu sich emporheben, und das Unendliche, was uns außerhalb der Kunst nur zu denken vergönnt ist, in einer Anschauung darstellen.” Emphasis in the original.

47. See Seifert, Christian Gottfried Körner, 114-15. On the connections between idealism and the concept of the characteristic, see Jacob de Ruiter, Der Charakterbegriff in der Musik: Studien zur deutschen Ästhetik der Instrumentalmusik, 1740-1850 (Stuttgart: Franz Steiner, 1989), 284-98. 
By the end of the 1790s, the concept of the artwork as a perceptible manifestation of the ideal was being articulated ever more systematically by such figures as Johann Gottlieb Fichte (1762-1814), Friedrich Wilhelm Joseph von Schelling (1775-1854), and August Wilhelm Schlegel (17671845). Schelling, in particular, insisted that art and philosophy were in the end concerned with the same basic issue: to reconcile the world of phenomena with the world of ideas. ${ }^{48}$ Schelling, like Schiller, saw profound meaning in the congruence of artistic and natural forms and considered the artwork to provide a window on their essential unity in the Absolute. In his System des transzendentalen Idealismus (1800), he advocated art as the key to perceiving the nature of this unity. His Philosophie der Kunst, in turn, based on lectures first delivered at Jena in 1802-3, has justly been called "the first explicit art-philosophy in the history of the Western world." 49 Art is the means by which the real and the finite can be synthesized with the ideal and the infinite. "Through art, divine creation is presented objectively, since it rests on the same idea of the infinite ideal dwelling in the real on which the creation of art rests. The exquisite German word Einbildungskraft actually means the power of forming into one, and in fact all creation is based on this power. It is the power through which an ideal is at the same time something real, the soul is the body; it is the power of individuation, which of all powers is the one that is truly creative."50

Within this framework, Schelling saw the "forms of music"-by this he meant rhythm, harmony, and melody-as "the forms of eternal things insofar as they can be contemplated from the perspective of the real. . . Thus music manifests, in rhythm and harmony, the pure form of the movements of the heavenly bodies, freed from any object or material. In this respect, music is that art which casts off the corporeal, in that it presents movement in itself, divorced from any object, borne on invisible, almost spiritual wings." Rhythm, harmony, and melody are the "first and purest forms of movement in the universe.... The heavenly bodies soar on the wings. of harmony and rhythm. . . Borne aloft by the same wings, music soars through space to weave an audible universe out of the transparent body of

48. On Schelling's philosophy of music, see August Steinkrüger, Die Aesthetik der Musik bei Schelling und Hegel: Ein Beitrag zur Musikästhetik der Romantik (Bonn: Verein Studentenwohl, 1927), esp. 150-64.

49. Manfred Frank, Einführung in die frübromantische Ästhetik (Frankfurt am Main: Suhrkamp, 1989), 16, 171. Although not published until 1859, these lectures circulated widely in manuscript from the first decade of the nineteenth century onward.

50. Friedrich Wilhelm Joseph von Schelling, Philosophie der Kunst, in his Sämmtliche Werke, ed. K. F. A. Schelling, 14 vols. (Stuttgart and Augsburg: J. G. Cotta, 1856-61), 5:386: "Durch die Kunst wird die göttliche Schöpfung objektiv dargestellt, denn diese beruht auf derselben Einbildung der unendlichen Idealität ins Reale, auf welcher auch jene beruht. Das treffliche deutsche Wort Einbildungskraft bedeutet eigentlich die Kraft der Ineinsbildung, auf welcher in der That alle Schöpfung beruht. Sie ist die Kraft, wodurch ein Ideales zugleich auch ein Reales, die Seele Leib ist, die Kraft der Individuation, welche die eigentlich schöpferische ist." 
sound and tone." ${ }^{1}$ Schelling openly acknowledged his debt to Pythagoreanism at this point, but insisted that Pythagorean theories had been quite poorly understood in the past.

On this basis, then, one might reasonably expect that Schelling would deem instrumental music to be the highest of all arts precisely on the basis of its incorporeality, which in turn would allow the greatest possible range of freedom for imaginative perception. For Schelling, however, the contemplation of the ideal was but a means to the end of achieving the Absolute, which he defined as the integration of the material and the spiritual, the phenomenal and the ideal. Although the artist and the philosopher pursue the same essential task, the former does so by using symbolic forms in a manner he himself does not fully understand. The material of the philosopher, by contrast, is rational thought, which can be more readily idealized and then reintegrated into the realm of the phenomenal. For this reason, Schelling preserved the traditional hierarchy that accorded place of honor to the verbal arts.

Schelling's work nevertheless provided an important philosophical context for the new aesthetics of instrumental music. He broke decisively with earlier systems based on the principle of mimesis, and he insisted on the metaphysical significance of all aesthetic intuition, including the perception of instrumental music. The potential realization of the Absolute through the contemplation of the artwork helps explain much of the sacred vocabulary and concepts found in the writings of Wackenroder, Tieck, and Hoffmann. In this respect, Schelling's philosophy of art (which is in fact a philosophy through art) represents a world qualitatively different from the one in which Kant, only a little more than a decade before, had deprecated instrumental music because of its purported inability to accommodate ideas. The rising tide of art-philosophy had raised the status of all artistic vessels, including that of instrumental music.

Schelling's philosophy reverberates throughout the subsequent history of idealist aesthetics. August Wilhelm Schlegel's lectures on art within his Vorlesungen über schöne Literatur und Kunst (1801-2) also pursue the idea that the beautiful is a symbolic representation of the infinite and that the infinite becomes at least partly perceptible through the beautiful. Schlegel

51. Ibid., 501-3:

Die Formen der Musik sind Formen der ewigen Dinge, inwiefern sie von der realen Seite betrachtet werden. . . . so bringt die Musik die Form der Bewegungen der Weltkörper, die reine, von dem Gegenstand oder Stoff befreite Form in dem Rhythmus und der Harmonie als solche zur Anschauung. Die Musik ist insofern diejenige Kunst, die am meisten das Körperliche abstreift, indem sie die reine Bewegung selbst als solche, von dem Gegenstand abgezogen, vorstellt und von unsichtbaren, fast geistigen Flügeln getragen wird. . . . Wir können jetzt erst die höchste Bedeutung von Rhythmus, Harmonie und Melodie festsetzen. Sie sind die ersten und reinsten Formen der Bewegung im Universum... Auf den Flügeln der Harmonie und des Rhythmus schweben die Weltkörper; ... Von denselben Flügeln erhoben schwebt die Musik im Raum, um aus dem durchsichtigen Leib des Lauts und Tons ein hörbares Universum zu weben. 
used this premise to expose the inadequacy of earlier psychological, empirical, and sensualist theories. Sound, according to Schlegel, is the "innermost" of the five senses, dealing with transitory phenomena in a play of successions; and music, as exemplified by the sound of the chorale (quite apart from any underlying text), provides us. with "an intimation of harmonic perfection, the unity of all being that Christians imagine through the image of heavenly bliss." 52 Because of its incorporeality, "one must accord music the advantage of being ideal in its essence. It purifies the passions, as it were, from the material filth with which they are associated, in that music presents these passions to our inner sense entirely according to their form, without any reference to objects; and after touching an earthly frame, it allows these passions to breathe in a purer ether."53

\section{Idealism in Early Romantic Musical Aesthetics}

Although seldom identified as such, idealist vocabulary and categories of thought figure prominently in the musical aesthetics of the early Romantics. Wackenroder, Tieck, Hoffmann, and others consistently portrayed music as the reflection of a higher, spiritual realm. The emphasis on specific points varies from writer to writer, but the basic terms and concepts derive from idealist philosophy.

This outlook is evident throughout the fiction of Jean Paul (17631825). In his early Die unsichtbare Loge (1793), for example, he invokes the Pythagorean idea of the harmony of the spheres with such outbursts as "Oh, Music! Echo from a distant harmonic world! Sighing of the angels within us!"54 Elsewhere, he refers in passing to the "spirit world," "infinite longing," and the "inner world" associated with music. His Vorschule der Asthetik (1804), although concerned primarily with literature, adopts a fundamentally idealist stance, particularly in its emphasis on the relationship of the cosmic to the corporeal, one of the central elements in his theory of irony.

52. August Wilhelm Schlegel, Vorlesungen über schöne Literatur und Kunst. Erster Teil: Die Kunstlehre (1801-2), in his Kritische Ausgabe der Vorlesungen, ed. Ernst Behler (Paderborn: Ferdinand Schöningh, 1989- ), 1:381: "eine Ahndung der harmonischen Vollendung, der Einheit alles Daseyns, welche die Christen sich unter dem Bilde der himmlischen Seligkeit denken.”

53. Ibid., 375: "so muß man der Musik den Vorzug zugestehn, ihrem ganzen Wesen nach idealisch zu seyn. Sie reinigt die Leidenschaften gleichsam von dem materiellen, ihnen anhängenden Schmutz, indem sie selbige ohne Bezug auf Gegenstände bloß nach ihrer Form in unserem innern Sinn darstellt; und läßt sie nach Abstreifung der irdischen Hülle in reinerem Aether athmen."

54. Jean Paul, Die unsichtbare Loge (1793), in his Werke, 9 vols., ed. Norbert Miller (Munich: Carl Hanser, 1959-85), 1:60: "O Musik! Nachklang aus einer entlegenen harmonischen Welt! Seufzer des Engels in uns!” 
In scattered aphorisms, Novalis (Friedrich von Hardenberg, 17721801) similarly emphasized the Pythagorean, quasi-mystical nature of music, and indeed, of language itself. And it is within the broader context of idealism that we can best appreciate the assertion of Friedrich Schlegel (1772-1829) that music has "more affinity to philosophy than to poetry." Indeed, Schlegel pronounced the need for "all pure music" to be "philosophical and instrumental," and he urged others to go beyond considering instrumental music from "the flat perspective of so-called naturalness"that is, from the mechanistic perspective of cause and effect-and to recognize it instead as a vehicle of philosophy. ${ }^{55}$

It is against this background that Wilhelm Heinrich Wackenroder (1773-1798) emerged as the single most important figure in the articulation of a new aesthetic of instrumental music at the end of the eighteenth century. Unlike most of the other writers discussed up to this point (with the notable exception of Körner), Wackenroder had substantial training in music. He received early instruction in his native Berlin from Karl Fasch, founder of the Singakademie, and he appears to have tried his hand at composition as well. ${ }^{56}$ At Göttingen, Wackenroder studied under the theorist, historian, and composer Johann Nikolaus Forkel, and his keyboard skills were good enough to have elicited an invitation from a musical society in Bamberg for a public performance of a concerto by Haydn. ${ }^{57}$ In the last years of his brief life, he collaborated with his friend Ludwig Tieck (17731853), a poet and playwright who in turn was responsible for the posthumous (albeit anonymous) publication of Wackenroder's Phantasien über die Kunst (1799), to which Tieck added several essays of his own. ${ }^{58}$

Wackenroder's first major publication, the Herzensergiessungen eines kunstliebenden Klosterbruders (1796), attracted immediate attention. Published anonymously, these "Outpourings from the Heart of an Art-Loving Monk" were thought for a time to have been written by none other than Goethe himself, and there was sufficient demand for the work to be reissued (along with the Phantasien) in a second edition in 1814. The Herzensergiessungen and Phantasien incorporate all the essential elements of the idealist aesthetic. Nature and art are "two wondrous languages" of "mysterious power" granted to us by God "in order that mortals might

55. Kritische Friedrich-Schlegel-Ausgabe, ed. Ernst Behler (Munich and Paderborn: Ferdinand Schöningh, 1958- ), 18:361; 16:178; 2:254. On the historical context of the last of these aphorisms, see Bonds, Wordless Rhetoric, 166-67.

56. Rudolf Köpke, Ludwig Tieck: Erinnererungen aus dem Leben des Dichters (Leipzig: Brockhaus, 1855; reprint, Darmstadt: Wissenschaftliche Buchgesellschaft, 1970), 183.

57. See Wackenroder to his parents, letter of 23 July 1793, in his Sämtliche Werke 2:196.

58. On the troublesome questions of authorship in the collaborative publications of Wackenroder and Tieck, see the commentary to Wackenroder's Sämtliche Werke 1:283-88 and $368-72$. 
grasp (as fully as possible) heavenly things in their full power."59 Joseph Berglinger, Wackenroder's fictitious musician, declares music to be "the most wondrous" of all the fine arts because "it represents human emotions in a superhuman manner" and "shows us all the movements of our emotions in a manner that is incorporeal, clothed in golden clouds of ethereal harmonies, above our heads." "the language of angels." It is the "only art that leads us back to the most beautiful harmonies of the manifold and contradictory movements of our emotions." 61 Here we see the reintegration of the ideal with the phenomenal first expounded by Fichte and applied more specifically to the arts (slightly later) by Schelling.

Music is the darkest and most powerful of all the arts. Its "waves" stream forth with "pure and formless essence . . . and particularly the thousandfold transitions among the emotions. In its innocence, this idealistic, angelically pure art knows neither the origins nor the impetus for its motions, and it does not know the relationship of its feelings with the actual world."62 Here, Wackenroder encapsulates the creed of idealist aesthetics with remarkable concision. Music occupies a separate world of ideals, independent of earthly objects and emotions, and it has the power to lift us out of the ills of life to a higher region. In Wackenroder's writings, we find virtually no attempt to explain a cause-and-effect relationship between work and listener, for the fundamental nature of discourse on music has changed: the perspective is no longer even remotely naturalistic.

Tieck shared these views on the essence of instrumental music, strenuously disavowing any connection of this art with the phenomenal world. Instead, he emphasized that musical notes "constitute a separate world unto themselves." 63 In one of the very few extended discussions of a specific

59. Wackenroder, Herzensergiessungen, "Von zwey wunderbaren Sprachen, und deren geheimnißvoller Kraft," in his Sämtliche Werke 1:97. Published in December of 1796, the title page of Wackenroder's work bears the date 1797.

60. Wackenroder, Phantasien, "Die Wunder der Tonkunst," in his Sämtliche Werke 1:207: "Die Musik aber halte ich für die wunderbarste dieser Erfindungen [the fine arts], weil sie menschliche Gefühle auf eine übermenschliche Art schildert, weil sie uns alle Bewegungen unsers Gemüths unkörperlich, in goldne Wolken luftiger Harmonieen eingekleidet, über unserm Haupte zeigt."

61. Ibid., 208: "Sie ist die einzige Kunst, welche die mannigfaltigsten und widersprechendsten Bewegungen unsres Gemüths auf dieselben schönen Harmonieen zurückführt."

62. Wackenroder, Phantasien, "Das eigentümliche innere Wesen der Tonkunst, und die Seelenlehre der heutigen Instrumentalmusik," in his Sämtliche Werke 1:220: "in diesen Wellen strömt recht eigentlich nur das reine, formlose Wesen, der Gang und die Farbe, und auch vornehmlich der tausendfältige Übergang der Empfindungen; die idealische, engelreine Kunst weiß in ihrer Unschuld weder den Ursprung noch das Ziel ihrer Regungen, kennt nicht den Zusammenhang ihrer Gefühle mit der wirklichen Welt."

63. Tieck, Phantasien, "Die Töne," in Wackenroder's Sämtliche Werke 1:236: “diese Töne ... ahmen nicht nach, sie verschönern nicht, sondern sie sind eine abgesonderte Welt für sich selbst." 
work of music by early Romantic writers, he praised Johann Friedrich Reichardt's overture to a German-language adaptation of Shakespeare's Macbeth (1787). Tieck's choice of works has been widely misunderstood: it has been suggested that he knew nothing of the music of Haydn and Mozart, but this seems implausible for an artist living in Berlin during the late 1790 s. ${ }^{64}$ Reichardt's music to Macbeth was quite well known at the time, ${ }^{65}$ and Tieck chose an overture to a spoken drama in order to contrast the music with the subsequent stage production, arguing that purely instrumental music was capable of projecting its own complete and selfcontained "drama" of a kind that "no poet could ever give us." The music itself was a drama without characters that relied on no laws of probability and referred to no story. ${ }^{66}$ And in order to emphasize the greater emotional power of instrumental music over the verbal arts, Tieck selected a work associated with one of the greatest of all dramas by none other than Shakespeare himself. Quite aside from all this, Reichardt happened to be a close friend of Tieck's.

Wackenroder and Tieck were both young men when they presented their idealist aesthetic of instrumental music. Many older writers understandably clung to more traditional outlooks well into the nineteenth century: Goethe, for one, appears never to have embraced the enhanced aesthetic status of instrumental music. Like many writers before him, he likened the string quartet to a conversation among four intelligent individuals, but the implicit imagery of music as a language was already oldfashioned by this time. Other critics shifted their allegiance to the aesthetics of idealism during the closing years of the eighteenth century and the first decade of the nineteenth. The writings of Johann Gottfried Herder (17441803 ) illustrate this change particularly well, for his views on the nature and aesthetic worth of instrumental music changed markedly over the course of his life. His fourth Kritisches Wäldchen (written in 1769 but not published until 1846) maintained the conventional image of music as a language of passions, and within this conceptual design, instrumental music inevitably suffers because of its semantic obscurity. By the mid 1780s, Herder's views had begun to change. In an essay of 1785 entitled "Which Produces the Greatest Effect, Painting or Music? A Dialogue of the Gods,"

64. See, for example, Carl Dahlhaus, "Romantische Musikästhetik und Wiener Klassik," Archiv für Musikwissenschaft 29 (1972): 174.

65. The enduring popularity of Reichardt's incidental music to Macbeth was remarkable: A. B. Marx was still writing enthusiastically about it as late as 1824 . See Walter Salmen, Jobann Friedrich Reichardt (Zurich: Atlantis, 1963), 281-83.

66. Tieck, Phantasien, "Symphonien," in Wackenroder's Sämtliche Werke 1:244. Because of its all-encompassing nature in the realm of instrumental music, the symphony was the genre most often used at this time to illustrate the ideal in music. I shall pursue this connection in greater detail in a forthcoming book dealing with critical perceptions of the symphony in the eighteenth and nineteenth centuries. 
Apollo presides over a dispute between the goddess of music and the goddess of painting. Painting charges that Music is dark and confusing. Music responds that what is

dark and confused in your emotions is due to your organ of perception, not my tones, which are pure and clear, the highest model of harmonious order. They are (as was once pointed out by a wise mortal inspired by me) the relationship and numbers of the universe in the most pleasant, facile, and powerful of all symbols. In criticizing me, my sister, you have therefore praised me. You have praised the infinite quality of my art in its innermost workings.

The goddess of poetry is summoned to judge the debate and finds in favor of Music, but reminds her "that without my words, without song, dance, or other action, you must concede that for humans, your emotions remain perpetually in the dark. You speak to the heart, but to the understanding of how very few!"67 The location of the debate on Mount Olympus is particularly revealing, for while Poetry reiterates the then-standard view that only through word or gesture can music become intelligible, she does so from a perspective that suggests this aesthetic stance to be dictated more by necessity than desirability.

Herder's late Kalligone (1800), in turn, reads like a thoroughly idealist tract. In rebutting Kant's Kritik der Urteilskraft, Herder unambiguously declared instrumental music to be the highest of all the arts because it provides a means of perceiving the Absolute. Music surpasses all other arts in the way the spirit surpasses the body, for music is spirit-Geist-"related to motion, great nature's innermost power. What cannot be made visible to man - the world of the invisible - becomes communicable to him in its manner, and in its manner alone."68 Ten years before E. T. A. Hoffmann's review of Beethoven's Fifth Symphony, Herder spoke of “infinite longing” (unendliche Sehnsucht) in conjunction with the process of listening, and he emphasized Andacht-reverent contemplation-as the cognitive quality

67. Johann Gottfried Herder, “Ob Malerei oder Tonkunst eine grössere Wirkung gewähre? Ein Göttergespräch” (1785), in his Sämmtliche Werke, ed. Bernhard Suphan, 33 vols. (Berlin: Weidmann, 1877-1913), vol. 15: "Das Dunkle und Verworrene ihrer Empfindungen liegt an ihrem Organ, nicht an meinen Tönen: diese sind rein und helle, das höchste Muster einer zusammenstimmenden Ordnung. Sie sind, wie schon ein von mir begeisterter sterblicher Weise gesagt hat, die Verhältnisse und Zahlen des Weltalls im angenehmsten, leichtesten, wirkendsten aller Symbole. Du hast mich also, Schwester, gelobt, indem du mich tadelst. Du hast das Unendliche meiner Kunst und ihrer innigsten Wirkung gepriesen" (p. 228). "Du wirst mir aber zugeben, dass ohne meine Worte, ohne Gesang, Tanz und andre Handlung, für Menschen deine Empfindungen immer im Dunkeln bleiben. Du sprichst zum Herzen; aber bei wie wenigen zum Verstande!” (p. 231).

68. Herder, Kalligone, in his Sämmtliche Werke 22:187: “denn sie ist Geist, verwandt mit der großen Natur innersten Kraft, der Bewegung. Was anschaulich dem Menschen nicht werden kann, wird ihm in ihrer Weise, in ihrer Weise allein, mittheilbar, die Welt des Unsichtbaren." 
that moves the listener to a "high, free realm" when hearing music without words. A more spiritual version of Kant's Einbildungskraft, Herder's Andacht implies a sense of contemplation with reverence for the divine, the infinite. ${ }^{69}$ Through reverent contemplation, the aesthetic experience was now seen to take place in a transcendent sphere, "pure and free above the earth."70 Herder's insight is critical to understanding the Romantic aesthetic, for it was not a change in the contemporary repertory that was transporting listeners to a higher realm, but rather a change in the perceived nature of aesthetic cognition.

Christian Friedrich Michaelis (1770-1834), although only slightly older than Wackenroder and Tieck, is another writer whose works reveal a similar change in aesthetic. Michaelis published two separate essays entitled Über den Geist der Tonkunst (1795 and 1800), both of which take as their point of departure Kant's Kritik der Urteilskraft. Although clearly familiar with the principles of idealism and willing to grant instrumental music a higher aesthetic status than had Kant, Michaelis adhered to the traditional view of instrumental music as "more pleasure than culture." in an essay entitled "On the Ideal in Music," Michaelis had abandoned the naturalist perspective and openly embraced idealism. Music "presents entirely and purely the spirit of art in its freedom and individuality" and conjures up before our fantasy "such an entirely individual world that we would search in vain for an original in artless reality." 72 The ecstasy of Wackenroder and Tieck is missing, but the perspective is recognizably the same.

Michaelis's "conversion" to idealism is fairly typical of his time. The notion of the artwork - and the work of music, in particular-as an earthly manifestation of the Absolute won widespread acceptance in the first decade of the nineteenth century. ${ }^{73}$ The vocabulary of idealism pervades much of the criticism written during this time: music is widely described as "supernatural," "mystic," "holy," "divine," "heavenly." The mechanical

69. Andacht has been translated in a variety of ways: as "reverence" (Lippman, Musical Aesthetics 2:40); as "devotion" (Lustig's translation of Dahlhaus, Idea of Absolute Music, 79); and as "religious awe" (Peter le Huray and James Day, eds., Music and Aesthetics in the Eighteenth and Early-Nineteenth Centuries [Cambridge: Cambridge University Press, 1981], 257). I prefer "reverent contemplation" because it combines both humility and active thought (-dacht derives from denken, "to think"), whereas "devotion" overemphasizes the religious element, and "awe" connotes a stunning of the senses, as if they were incapable of operating actively and independently.

70. Herder, Kalligone, 187.

71. Christian Friedrich Michaelis, Über den Geist der Tonkunst, 2 vols. (Leipzig, 17951800; reprint, Brussels: Culture et Civilisation, 1970), 1:11, 12 (idealism); 1:25, 2:30 (pleasure vs. culture).

72. Christian Friedrich Michaelis, "Ueber das Idealische der Tonkunst," Allgemeine musikalische Zeitung 10 (13 April 1808): 449-52.

73. See Peter Schnaus, E. T. A. Hoffmann als Beethoven-Rezensent der Allgemeinen Musikalischen Zeitung (Munich: Emil Katzbichler, 1977), 84-88. 
associations with the passions, although still very much a topic of debate, were no longer the central concern they had been only a short time before; instead, the emphasis had shifted toward the premise that music is the reflection of a higher, more spiritual realm. The anonymous reviewer of Wackenroder and Tieck's Phantasien in Leipzig's Allgemeine musikalische Zeitung, for one, seems to have taken the idealist aesthetic as a given: the essence of art, he observes almost in passing, is to "manifest the suprasensuous, to unite the finite and the infinite." And it was a mistake, this reviewer argues, to draw a parallel between sounds and colors (in Wackenroder's essay "Die Töne") on the grounds that the corresponding play of sensations between sounds implicitly relegates music to the agreeable rather than the fine arts. ${ }^{74}$ Idealist premises are also evident in the lengthy and perceptive "Observations on the Development of Music in Germany in the Eighteenth Century" by Johann Triest, a pastor in Stettin, published in the Allgemeine musikalische Zeitung in 1800-1801. Triest argued that instrumental music is no mere receptacle for vocal music, nor is it derived from it, but instead is fully capable of incorporating aesthetic ideas. Triest thus preserved Kantian terminology while extending the domain of instrumental music beyond the realm of the merely sensuous. Even more so than vocal music, instrumental music is able to incorporate "spirit and life" by intimating an ideal. ${ }^{75}$ In the works of Shakespeare and Mozart, according to the playwright, novelist, and critic Franz Horn, writing in 1802, there is no longer "any conflict between the ideal and the real, the internal and the external"; instead, the "infinite is made manifest for the fantasy" of the beholder. ${ }^{76}$ And it is altogether telling that Heinrich Christoph Koch should include an entry "Ideal" in the abridged version of his musical dictionary of 1807 , even though none is to be found in the much larger original edition of $1802 .{ }^{77}$

E. T. A. Hoffmann (1776-1822) thus appeared on the scene of idealist aesthetics at a relatively late stage: the basic concepts and vocabulary of his music criticism were already well established by the time he began writing reviews for the Allgemeine musikalische Zeitung in 1809. Hoffmann's particular contribution lies in his superior prose and his ability to integrate philosophical and aesthetic concepts with more technical issues of musical

74. Review of Phantasien über die Kunst . . . von Ludwig Tieck (Hamburg: Perthes, 1799), Allgemeine musikalische Zeitung 2 (5 March 1800): 401-7.

75. [Johann] Triest, "Bemerkungen über die Ausbildung der Tonkunst in Deutschland im achtzehnten Jahrhundert," Allgemeine musikalische Zeitung 3 (28 January 1801): 301, 297.

76. Franz Horn, "Musikalische Fragmente," Allgemeine musikalische Zeitung 4 (24 March 1802): 422. Horn (1781-1837) had already achieved acclaim as the author of the popular drama Der Fall der Schweiz.

77. Heinrich Christoph Koch, Kurzgefasstes Handwörterbuch der Musik (Leipzig, 1807; reprint, Hildesheim: Olms, 1981); idem, Musikalisches Lexikon (Frankfurt am Main: A. Hermann der jüngere, 1802). The entry for "ideal" emphasizes the freedom of the listener's imagination and speaks of a "poeticized world" (erdichtete Welt) within which the images of our fantasy can play. 
detail. Like earlier writers, Hoffmann perceived music as occupying an altogether separate sphere beyond the phenomenal, thereby endowing musical works with the power to provide a glimpse of the infinite. He alludes to Plato's cave when he speaks of instrumental music and its power to make listeners "aware of giant shadows that surge back and forth." This music "discloses to man an unknown realm, a world that has nothing in common with the external sensuous world that surrounds him, a world in which he leaves behind him all feelings that can be expressed through concepts, in order to surrender himself to that which cannot be expressed" in words. In vocal music, it is only because the text is "clothed by music with the purple luster of romanticism" that we can be led into "the realm of the infinite."

As in earlier writings influenced by the idealist aesthetic, Hoffmann's music criticism abounds with sacred metaphors. He adopted Schelling's view of the artist as a high priest capable of providing mankind with a glimpse of a distant "spirit-realm," and he perceived musical harmony as "the image and expression of the communion of souls, of union with the eternal, with the ideal that rules over us and yet includes us." 79 Hoffmann saw the origins of music in the liturgy of the church and emphasized that music's divine nature had now extended into the secular sphere as well. Thus, while he acknowledged that "instrumental music had elevated itself in recent times to a level of which the old masters [before Haydn and Mozart] had no concept," 80 it is important to recognize that his aesthetic applies to vocal as well as instrumental music, and not merely to the music of the present and recent past. The sacred works of Palestrina and Leo are just as capable of providing a glimpse of the divine as are the symphonies of Haydn, Mozart, and Beethoven. Beethoven's instrumental compositions may have provided Hoffmann with the immediate impetus for some of his most inspired essays, but not with the philosophical and aesthetic outlook that underlies these writings.

Within the repertory of Hoffmann's own lifetime, the "sole object" of instrumental music had become "the infinite." ${ }^{81}$ Instrumental music is "the mysterious language of a distant spirit-realm whose accents resonate within

78. E. T. A. Hoffmann, review of Beethoven's Fifth Symphony (1810), in his Schriften zur Musik, 34: "Die Musik [specifically, instrumental music] schliesst dem Menschen ein unbekanntes Reich auf; eine Welt, die nichts gemein hat mit der äussern Sinnenwelt, die ihn umgibt, und in der er alle durch Begriffe bestimmbaren Gefühle zurücklässt, um sich dem Unaussprechlichen hinzugeben."

79. Hoffmann, "Alte und neue Kirchenmusik," 215: "und so wird der Akkord, die Harmonie, Bild und Ausdruck der Geistergemeinschaft, der Vereinigung mit dem Ewigen, dem Idealen, das über uns thront und doch uns einschliesst."

80. Hoffmann, review of Friedrich Witt's Symphony No. 5 (1809), in his Schriften zur Musik, 19.

81. Hoffmann, "Beethovens Instrumentalmusik" (1813), in his Fantasie- und Nachtstücke, ed. Walter Müller-Seidel (Munich: Winkler, 1960), 41. Hoffmann added this phrase in reworking portions of his earlier review of Beethoven's Fifth Symphony into this essay. 
us and arouse a heightened, more intensive life. All the passions, shimmering and splendidly arrayed, fight among themselves and submerge in an ineffable longing that fills our breast." When united with a text, music is forced to descend to the realm of common, everyday life and "speak of specific passions and actions. . . . Can music proclaim anything else but the wonders of that region from which it descends to us to resound?" In an utter reversal of traditional aesthetic hierarchies, Hoffmann left open the possibility that vocal music could achieve the exalted realm of instrumental music if the poet could raise himself to the level of the composer and do justice to the music. ${ }^{82}$

\section{The Idea of Absolute Music?}

It is by no means coincidental that the idealist aesthetic arose more or less simultaneously with the first extended use of poetic imagery to describe works of instrumental music that give no outward indication of a poetic "content." 83 Altt:ough such accounts now strike us as trivial and naive, they manifested in their own time a fundamentally new way of approaching instrumental music, for they rest on the notion that a work without a text can in fact represent something beyond itself that is not merely literal (e.g., thunder, birdcalls) and more than merely generic (e.g., anger, tenderness, grief). Somewhat paradoxically, the liberty to "poeticize" is directly proportional to the abstractness of the musical representation. Once it is acknowledged that music can provide only a dim, imperfect reflection of a noumenal world, critics are in a sense liberated from the obligation to provide detailed correspondences between a work of music and the phenomenal world. The question, then, is not to what degree a particular work of instrumental music might be representational of a particular object or psychological state, but rather, to what degree a composer might choose to articulate his vision of the work's ideal through verbal means. Beethoven's Eroica and Pastoral Symphonies are two celebrated examples of a composer designating that ideal within the title of a work. Critics struggled with the

82. Hoffmann, "Der Dichter und der Komponist" (1813), in his Die Serapionsbrüder: Gesammelte Erzählbungen und Märchen, ed. Hans-Joachim Kruse (Berlin: Aufbau-Verlag, 1978), 100:

Ist nicht die Musik die geheimnisvolle Sprache eines fernen Geisterreichs, deren wunderbare Akzente in unserm Innern widerklingen und ein höheres, intensives Leben erwecken? Alle Leidenschaften kämpfen, schimmerned und glanzvoll gerüstet, miteinander und gehen unter in einer unaussprechlichen Sehnsucht, die unsere Brust erfüllt. Dies ist die unnennbare Wirkung der Instrumentalmusik. Aber nun soll die Musik ganz ins Leben treten, sie soll seine Erscheinungen ergreifen, und Wort und Tat schmückend, von bestimmten Leidenschaften und Handlungen sprechen. ... Kann denn die Musik etwas anderes verkünden als die Wunder jenes Landes, von dem sie zu uns herübertönt?

83. See Bonds, Wordless Rhetoric, 169-76. 
narrowness of more explicit narratives for these works, and it is important to remember that A. B. Marx's celebrated "program" of the Eroica appears within a larger philosophical discourse on the nature of "ideal music." 84 In this sense, the idealist aesthetic helps reconcile the paradox that the same writers who considered the content and power of instrumental music so ineffable should also have written more about those very qualities than any generation before them.

The idealist aesthetic of instrumental music that arose around 1800 should therefore not be confused with the aesthetic of "absolute" music that began to emerge toward the middle of the nineteenth century. The two are closely related, to be sure, but it is important to recognize their fundamental differences. Their common ground and their historical divergence around the middle of the nineteenth century emerge with special clarity in Eduard Hanslick's Vom Musikalisch-Schönen, first published in 1854 and revised by the author for no fewer than nine subsequent editions. By tracing the fate of idealist thought through these editions, we can better understand the emergence of the dichotomy between "absolute" and "program" music.

Hanslick's treatise was a carefully reasoned response to the growingand largely unquestioned-legitimacy of "program" music in the second quarter of the nineteenth century. Within the broader tendency to integrate music with the literary, visual, and plastic arts, composers were becoming increasingly willing to make explicit connections between works of instrumental music and objects or ideas lying beyond the realm of sound. Attempts to legitimize the aesthetic basis of works like Berlioz's Symphonie fantastique and Liszt's symphonic poems eventually fostered a backlash from those who felt that such works encroached on music's "true" essence, and Hanslick's Vom Musikalisch-Schönen quickly emerged as the central manifesto of these musical "conservatives."

Within this debate, Hanslick's brief comments on idealism in the first edition of his treatise are particularly striking. At the very end of his argument in favor of viewing music as a purely formal art, without representational content, Hanslick conceded that there is a "spiritual content" in the "disposition of the listener" that "unites the beautiful in music with all other great and beautiful ideas." The sentences that immediately follow, however, were deleted by Hanslick in the second (1858) and all later editions of his book:

It is not merely and absolutely through its own intrinsic beauty that music affects the listener, but rather at the same time as a sounding image of the great motions of the universe. Through profound and secret connections to nature, the meaning of tones is elevated high above the tones themselves,

84. Adolf Bernhard Marx, Ludwig van Beethoven: Leben und Schaffen, 2 vols. (Berlin, 1859; reprint, Hildesheim: Georg Olms, 1979), 1:256-96. 
allowing us to perceive at the same time the infinite in works of human talent. Because the elements of music-sound, tone, rhythm, loudness, softnessare to be found throughout the entire universe, so does one find anew in music the entire universe. 85

The significance of this passage - and of its subsequent deletion-can scarcely be overestimated. This was not merely one of many pronouncements buried deep within Vom Musikalisch-Schönen, but rather the ringing culmination of Hanslick's entire treatise. Nor was the idealism of Hanslick's peroration sudden or isolated. The first edition includes another passage, deleted from all succeeding editions, that appears at an equally crucial juncture, immediately before one of the work's most frequently quoted assertions, that "sounding forms in motion are the sole and exclusive content and object of music." The original passage (with the later deletions shown below in italics) reads:

If we now ask what is to be expressed with this tone-material, then the answer is: musical ideas. A musical idea brought to its appearance is already autonomous beauty; it is already an end in itself and in no way primarily a medium or material for the representation of feelings and thoughts, even if it is capable of possessing, at the same time, a high degree of symbolic significance in its reflection of the great laws of the world, which is something we find in all artistic beauty. Sounding forms in motion are the sole and exclusive content and object of music. ${ }^{86}$

85. Eduard Hanslick, Vom Musikalisch-Schönen: Ein Beitrag zur Revision der Ästhetik in der Tonkunst, ed. Dietmar Strauß, 2 vols. (Mainz: Schott, 1990), 1:171:

Dieser geistige Gehalt verbindet nun auch im Gemüth des Hörers das Schöne der Tonkunst mit allen andern großen und schönen Ideen. Ihm wirkt die Musik nicht blos und absolut durch ihre eigenste Schönheit, sondern zugleich als tönendes Abbild der großen Bewegungen im Weltall. Durch tiefe und geheime Naturbeziehungen steigert sich die Bedeutung der Töne hoch über sie selbst hinaus und läßt uns in dem Werke menschlichen Talents immer zugleich das Unendliche fühlen. Da die Elemente der Musik: Schall, Ton, Rhythmus, Stärke, Schwäche im ganzen Universum sich finden, so findet der Mensch wieder in der Musik das ganze Universum.

From the third edition (1865) onward, Hanslick went even further to suppress any appeal to idealism, deleting the first sentence about the "spiritual content" being united within the "disposition of the listener." Because it is based on the eighth German edition (1891), the best available English translation of Hanslick's treatise, by Geoffrey Payzant (On the Musically Beautiful [Indianapolis: Hackett, 1986]), does not include the material quoted here.

86. Hanslick, Vom Musikalisch-Schönen 1:75:

Frägt es sich nun, was mit diesem Tonmaterial ausgedrückt werden soll, so lautet die Antwort: Musicalische Ideen. Eine vollständig zur Erscheinung gebrachte musikalische Idee aber ist bereits selbstständiges Schöne, ist Selbstzweck und keineswegs erst wieder Mittel oder Material zur Darstellung von Gefühlen und Gedanken; wenn sie gleich in hohem Grad jene symbolische, die großen Weltgesetze wiederspiegelnde Bedeutsamkeit besitzen kann, welche wir in jedem Kunstschönen vorfinden. Tönend bewegte Formen sind einzig und allein Inhalt und Gegenstand der Musik.

Hanslick emended the final sentence from the third edition (1865) onward to read, "Der Inhalt der Musik sind tönend bewegte Formen." 
Hanslick's deleted passages echo the tradition of German aesthetic idealism, which had continued to flourish in the decades after Hoffmann. ${ }^{87}$ Yet many of Hanslick's contemporaries sensed a fundamental opposition between idealism and formalism. At the end of an otherwise laudatory review that appeared shortly after the publication of Vom MusikalischSchönen, Hanslick's friend Robert Zimmerman asked why the author should have concluded his treatise by "invalidating" the "golden truth" of his central thesis with the idea that music might also be a sounding reflection of the motions of the universe. Zimmerman surmised that in summarizing the opinions he sought to discredit, Hanslick had been unconsciously overwhelmed by those very ideas. ${ }^{88}$ Hanslick would later dedicate the second and most subsequent editions of Vom Musikalisch-Schönen to Zimmerman, and he took his friend's closing criticism to heart in making revisions for that second edition.

But Zimmerman was too quick to equate idealism with the aesthetic of expressive content. The musical "right" and "left" either did not see or chose to ignore the underlying compatibility of Hanslick's formalist position with idealism, probably because idealism also happened to be compatible with the phenomenon of program music, as exemplified at the time by Berlioz and Liszt - that is, by composers whose works represented the very aesthetic Hanslick was attacking. The idealist aesthetic does not preclude use of programmatic titles or even a detailed program, on the grounds that any verbal interpretation is necessarily limited. As we have seen, idealism actually gave composers and critics unprecedented liberty to explicate instrumental works. A reflection of an abstract ideal, in the end, is quite different from the representation of a specific object or event. Without citing Hanslick by name, A. B. Marx conceded, in 1859, that the "interplay of tones is the primordial essence of music [Urmusik]; it has always been and will always be the mother earth from which everything that lives in music draws its life's power, its existence." Marx went on to insist, however, that man cannot

play endlessly and without a goal. Above all, he seeks himself in the play, the play should be his play; it should have the imprint, the expression of his being.

87. Limitations of space preclude even a summary review here of idealism in musical aesthetics between Hoffmann and Hanslick. Aside from Hegel and Schopenhauer (treated briefly below), such a review would necessarily include Hans Christian Oersted, Karl Wilhelm Ferdinand Solger, Hans-Georg Nägeli, Gustav Schilling (whose Encyclopädie der gesammten musikalischen Wissenschaften of 1835-38 includes an extended entry "Ideal"), Robert Schumann, Ferdinand Hand, and Adolf Bernhard Marx, among others.

88. Robert Zimmerman, review of Hanslick's Vom Musikalisch-Schönen, originally published in Oesterreichische Blätter für Literatur und Kunst (1854) and republished with minor changes in Zimmerman's Studien und Kritiken zur Philosophie und Aesthetik, vol. 2, Zur Aesthetik (Vienna: Wilhelm Braumüller, 1870), 253: "Mich dünkt, hier hat er sich unwillkürlich durch Reminiscenzen derselben Aesthetik überraschen lassen, die er sonst so schlagend und siegreich bekämpft!" 
Even in the play of tones, his fantasy seeks the feeling of his being. . . . It is precisely because man gives artistic form to the constraining relationships and moods of real life that he feels himself to be master of this self-created world. And in this transfigured reflection of the real world, he considers himself redeemed and free. ${ }^{89}$

Marx's comments resonate with Hanslick's own observation that the fantasy of the listener "gladly relates the ideas of art to its own human life of the soul" and perceives the motions of music in such a way that this fantasy can eventually "ascend to an intimation of the Absolute." Here again, however, Hanslick moderated his idealism over the course of later editions. ${ }^{90}$ Most writers of the day-including, it would seem, Hanslick himself-were more interested in polemics than in rapprochement, and most of Hanslick's opponents drew on idealism to at least some extent. ${ }^{91}$ In a review of Joachim Raff's Leonore Symphony in 1875, for example, the critic Gotthold Kunkel quoted Hanslick's idealistic (and already deleted) final paragraph in its entirety as a justification for programmatic titles in works of purely instrumental music. ${ }^{92}$

The irony of course is that Hanslick himself had recognized the compatibility of formalism and idealism, for otherwise he would have not written the two deleted passages in the first place. And throughout the many revisions of his celebrated treatise, Hanslick retained a number of other passages that are less overtly grounded in idealism. ${ }^{93} \mathrm{He}$ recognized that the aesthetics of idealism allowed instrumental music to retain its autonomy through, an intrinsically musical, self-referential content without thereby being isolated from "extramusical" ideas. The important distinction is that this "spiritual content" was seen to reside not in the music itself, but rather within the "disposition of the listener"- the Einbildungskraft for Kant, Andacht for Wackenroder and Herder.

In this respect, Hanslick's views are also essentially consistent with those of Georg Wilhelm Friedrich Hegel (1770-1831) and Arthur

89. Marx, Ludwig van Beethoven 1:276-77:

Das Spiel der Töne ist die Urmusik, es war und wird immer der Mutterboden sein, aus dem Alles, was in Musik lebt, seine Lebenskraft, sein Dasein zieht. Allein der Mensch kann . . . nicht end- und zwecklos fortspielen. Er sucht vor allen Dingen sich selber im Spiel, das Spiel soll Sein Spiel sein, das Gepräge, den Ausdruck Seines Daseins ... haben. Seine Phantasie sucht auch im Spiel der Töne das Gefühl seines Daseins. ... Eben darin aber, daß der Mensch die im realen Leben zwingenden Verhältnisse und Stimmungen in der Kunst selbst gestaltet, fühlt er sich Herr dieser selbstgeschaffenen Welt und von der realen Welt in diesem verklärenden Spiegelbild erlöst und frei.

90. Hanslick, Vom Musikalisch-Schönen 1:46. In the second edition (1858), Hanslick had asserted here that the "fantasy . . . can perhaps ascend to an intimation of the Absolute," but from the third edition (1865) onward, "the Absolute" is replaced with "an eternal, otherworldly peace" ("Ahnung eines ewigen jenseitigen Friedens").

91. See Lippman, History of Western Musical Aesthetics, 322. These writers include August Wilhelm Ambros, Friedrich Theodor Vischer, Adolf Kullak, and Moritz Carriere.

92. Gotthold Kunkel, "Die Programmmusik und Raff's Lenorensymphonie," Neue Zeitschrift für Musik 71 (1875): 65-66.

93. See, for example, the opening of chapter $2(I, 42)$ and later in the same chapter $(I, 45)$. 
Schopenhauer (1788-1860), both of whose writings are thoroughly imbued with the aesthetics of idealism, albeit in different ways. Hegel followed Kant in minimizing the status of instrumental music, calling it "empty and meaningless" on the grounds that it "lacks a principal factor of all art-spiritual content and expression." On this basis, indeed, "it could hardly be considered an art at all." 94 Hegel nevertheless argued that "the fundamental task of music" is to "give resonance not to objectivity but rather to the manner in which the innermost self is essentially moved according to its subjectivity and the ideal nature of the soul."95 Decades before Hanslick, Hegel had ascribed music's essence to its play of forms and left open the possibility of a higher "resonance" with the inner motions of the soul.

Schopenhauer, on the other hand, placed far greater weight on the ability of instrumental music to reflect the Absolute-so much so, in fact, that he ascribed to music the sole capacity among all the arts to reflect not merely an idea of the Will, but rather the Will itself. The effect of music is therefore much more powerful than that of all other arts, "which speak only of the shadow" of the Will. 96 "One could equally call the world embodied music or music the embodied Will; and from this it can be explained why music can allow every painting, indeed every scene of actual life and of the world, to step forward with enhanced significance."97 The real world of particular things consists of universalia in re, and concepts are universalia post rem, but music presents universalia ante rem, the "innermost kernel preceding all form." 98

Even Hanslick's most bitter opponent, Richard Wagner, would come to embrace idealism after his encounter with Schopenhauer's writings in the mid 1850s. In his essay "Beethoven," written in 1870 on the centennial of the composer's birth, Wagner proclaimed music to be "a comprehensive idea of the world." Music embraces drama, which in turn is "a counterpart

94. Georg Wilhelm Friedrich Hegel, Vorlesungen über die Ästhetik, ed. Eva Moldenhauer and Karl Markus Michel, 3 vols. (Frankfurt am Main: Suhrkamp, 1970) (his Werke, vol. 15), 3:148-49: "Dann bleibt aber die Musik [without text] leer, bedeutungslos und ist, da ihr die eine Hauptseite aller Kunst, der geistige Inhalt und Ausdruck abgeht, noch nicht eigentlich zur Kunst zu rechnen." Hegel's treatise on aesthetics, first published posthumously in 1835 , is based on lectures given in the 1820s.

95. Ibid., 135: "Die Hauptaufgabe der Musik wird deshalb darin bestehen, nicht die Gegenständlichkeit selbst, sondern im Gegenteil die Art und Weise widerklingen zu lassen, in welcher das innerste Selbst seiner Subjektivität und ideellen Seele nach in sich bewegt ist.”

96. Arthur Schopenhauer, Die Welt als Wille und Vorstellung, ed. Lilo Hess et al., 2 vols. (Zurich: Haffmans, 1988), 1:341. See Lawrence Ferrara, "Schopenhauer on Music as the Embodiment of Will," in Schopenhauer, Philosophy, and the Arts, ed. Dale Jacquette (Cambridge: Cambridge University Press, 1996), 183-99.

97. Schopenhauer, Welt 1:347: "Man könnte demnach die Welt ebenso wohl verkörperte Musik, als verkörperten Willen nennen; daraus also ist es erklärlich, warum Musik jedes Gemälde, ja jede Scene des wirklichen Lebens und der Welt, sogleich in erhöhter Bedeutsamkeit hervortreten lässt."

98. Ibid., 348. 
of music given visible form." Instrumental music, for the later Wagner, was nothing less than a bridge between the conscious, rational world, and the higher realm of the spirit that can otherwise be intuited only through dreams. ${ }^{99}$

By 1870, however, Hanslick had long since purged his treatise of all overt references to idealism. The growing polarization of musical thought in the second half of the nineteenth century is altogether evident in the polemically tinged foreword to the second edition of Vom MusikalischSchönen (1858), in which Hanslick notes that "Liszt's program symphonies [the Faust and Dante Symphonies] have now been added to Wagner's writings," and that these new musical works "have abdicated the independent meaning of music more fully than has ever been attempted." 100 Critics and aestheticians no longer perceived the fundamental compatibility of "absolute" and idealist aesthetics. More than any other single moment, Hanslick's deletion of the final sentences for the second edition reflects the emerging dichotomy between absolute and program music and thus the emergence of absolute music in the sense in which it is generally understood today - that is, in terms of what it is not. ${ }^{101}$

But to apply the term-or even the idea-of absolute music retrospectively to the repertory or aesthetics of the early nineteenth century is fundamentally mistaken. Hanslick's formalism would have been unthinkable in 1800 or 1810 , and perhaps even as late as 1840 . The concept of an autonomous, absolute music is something that Wackenroder, Tieck, or Hoffmann would have probably not even recognized, much less embraced. Pace Dahlhaus, the early Romantics did not espouse an idea of absolute music in either word or thought. ${ }^{102}$ While the early Romantics were quick

99. Richard Wagner, "Beethoven," in his Sämtliche Schriften und Dichtungen, 12 vols. (Leipzig: Breitkopf und Härtel, n.d.), 9:105 and 112. For a penetrating reevaluation of Wagner's changing attitudes toward the question of "absolute" music, including his confrontation with the writings of Schopenhauer, see Thomas S. Grey, Wagner's Musical Prose (Cambridge: Cambridge University Press, 1995). See also K. M. Knittel's article on Wagner's reception of Beethoven's late style, this Journal, forthcoming.

100. Hanslick, Vom Musikalisch-Schönen 1:10.

101. Dahlhaus (Idea of Absolute Music, 7) defines "the idea of absolute music" as "the conviction that instrumental music purely and clearly expresses the true nature of music by its very lack of concept, object, and purpose." See also Roger Scruton's observation in his entry "Absolute Music" in The New Grope Dictionary of Music and Musicians 1:26: "The best way to speak of a thing that claims to be 'absolute' is to say what it is not."

102. See Carl Dahlhaus, "E. T. A. Hoffmanns Beethoven-Kritik," Archiv für Musikwissenschaft 38 (1981): 80; idem, Idea of Absolute Music, 7, 142; and idem, "'Eine abgesonderte Welt für sich selbst," "Archiv für Musikwissenschaft 42 (1985): 162-65. Neubauer (Emancipation of Music, 194) argues for a change at this time from "an aesthetics of affects and expression to an aesthetics of structure," a formulation that is in itself strongly imbued with the formalist premises of "absolute" music. Geck (Von Beethoven bis Mabler) recognizes the strongly idealist elements in early nineteenth-century conceptions of instrumental music, but insists on using the term absolute to describe this repertory. In a sense, Geck's use of the term is more correct than Wagner's or Hanslick's, in that idealism considers music a vehicle for the 
to deny direct connections between instrumental music and the phenomenal world, they placed central emphasis on their conviction that music reflected an ideal world of the spirit, and that this separate world, however remote, could be made at least partially accessible through the vehicle of art. Unlike Hanslick (at least in the later editions of Vom MusikalischSchönen), the early Romantics preferred to emphasize what instrumental music was rather than what it was not. And in contrast even to the first edition of Hanslick's treatise, their understanding of instrumental music as an image of the Absolute lay at the very heart of their aesthetics; their idealism was not an additional "layer" superimposed on a formalistic substratum.

\section{Abstract}

The growing aesthetic prestige of instrumental music in the last decades of the eighteenth century was driven not so much by changes in the musical repertory as by the resurgence of idealism as an aesthetic principle applicable to all the arts. This new outlook, as articulated by such writers as Winckelmann, Moritz, Kant, Schiller, Herder, Fichte, and Schelling, posited the work of art as a reflection of an abstract ideal, rather than as a means by which a beholder could be moved. Through idealism, the work of art became a vehicle by which to sense the realm of the spiritual and the infinite, and the inherently abstract nature of instrumental music allowed this art to offer a particularly powerful glimpse of that realm. Idealism thus provided the essential framework for the revaluation of instrumental music in the writings of Wackenroder, Tieck, E. T. A. Hoffmann, and others around the turn of the century. While this new approach to instrumental music has certain points of similarity with the later concept of "absolute" music, it is significant that Eduard Hanslick expunged several key passages advocating idealist thought when he revised both the first and second editions of his treatise Vom Musikalisch-Schönen. The concept of "absolute" music, although real enough in the mid-nineteenth century, is fundamentally anachronistic when applied to the musical thought and works of the decades around 1800 .

perception of the Absolute. But usage calls for a distinction between the mid-nineteenth century's understanding of the term and the early nineteenth century's views on the nature of instrumental music. Walter Wiora ("Die Musik im Weltbild der deutschen Romantik," in Beiträge zur Geschichte der Musikanschauung im 19. Jabrbundert, ed. Walter Salmen [Regensburg: Gustav Bosse, 1965], 11-50) emphasizes the idealist element in early nineteenthcentury concepts of "absolute" music, pointing out that if music were detached from the realm of extramusical ideas, it would not have attained such importance in the minds of so many writers from this period. Robin Wallace (Beethoven's Critics: Aesthetic Dilemmas and Resolutions During the Composer's Lifetime [Cambridge: Cambridge University Press, 1986], 2-3 and passim) follows Wiora in this regard but like Zimmerman draws an overly sharp distinction between idealism and Hanslick's aesthetics of "absolute" music. 